\title{
Analysis on the Influencing Factors of Green Technological Innovation Efficiency_Based on the Perspective of the Law Construction and Banking Efficiency
}

\author{
Yuxin Zhang ${ }^{1}$, Chenghao Sun ${ }^{2, *}$, and Shuoxin Wang ${ }^{2}$ \\ ${ }^{1}$ School of Law, Shandong University, Qingdao, Shandong, China \\ ${ }^{2}$ School of Economics and Trade, Shandong Management University, Jinan, Shandong, China
}

\begin{abstract}
Based on provincial data from 2010 to 2016, this paper uses regression model to analyze the factors affecting the green technology innovation efficiency and discuss the impact from the perspective of law construction and banking efficiency. The result shows that the law construction significantly improves the green technology innovation efficiency while the banking efficiency has the opposite result. Therefore, it is necessary to optimize financial structure and strengthen the legal protection of technological innovation, and ultimately promote high-quality development.
\end{abstract}

\section{Introduction}

In recent years, facing the environmental pollution behind the rapid economic growth, China has emphasized the strategic plan of promoting green development and accelerating the ecological civilization construction in the report from the 19th Communist Party of China National Congress. Green technological innovation, as an important part of achieving goals of green development, aims to reduce pollution emissions and improve resource utilization, which is one of the main means to deal with the contradiction between economic development and environment. Green technology innovation depends on increasing green technology investment on the one hand, and on improving innovation efficiency on the other. Therefore, the influencing factors of green technological innovation efficiency have become a research hotpot in recent years. The green technological innovation efficiency is mainly determined by the input and output factors such as financial support and external system guarantee. This paper selects law construction and banking efficiency as two representative influencing factors of green technological innovation. Through regression equation and DEA method, this paper discusses the influence of the above factors on green efficiency, which provides theoretical support for enhancing the energy conservation and emission reduction and improving the quality of regional development.

Referring to green technological innovation efficiency, the present research mainly focuses on efficiency measurement and influencing factors. In terms of efficiency measurement, green technological innovation efficiency can be mainly measured by parametric methods represented by stochastic frontier (SFA) and non-parametric way represented by data envelopment (DEA). Cheng (2020) used the DEA model to measure the efficiency of green technological innovation in various industries, comparing and analyzing the efficiencies at the two stages of green technology R\&D and the conversion of green technology. In terms of influencing factors, the researches mainly focus on environmental regulation and enterprises ${ }^{[1]}$. Qian(2015) studied the theory of meta-frontier to analyze the enterprises' green R\&D efficiency and the technology gap between regions from 2003 to $2010^{[2]}$. $\mathrm{Li}$ (2017) found that corporate profitability has a positive impact on green product innovation, but has no significant impact on green process innovation ${ }^{[3]}$. Li (2018) suggested that in order to achieve the goal of sustainable development and environmental protection, the government will encourage enterprises to carry out green technology innovation, and the R\&D funds are conducive to the green technological innovation efficiency ${ }^{[4]}$. Some scholars also found that other economic and non-economic factors can affect innovation, and one important factor is law. Lu (2015) investigated the impact of investor protection environment and administrative environment on a country's technological innovation activities. It is found that more protection of investors by law can lead more capital investment and personnel investment in technological innovation. Previous studies have analyzed the green technical innovation efficiency from multiple perspectives, but there are few studies focusing on financial support and institutional guarante $\mathrm{e}^{[5]}$. Filippo (2013) found that the financial market can provide technology innovation with financial support and law construction offers external institutional guarante $e^{[6]}$. Therefore, this paper uses the provincial panel data from 2010 to 2016 to explore the influencing factors of green technological innovation efficiency from above two

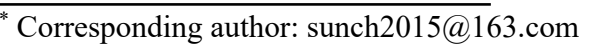


aspects, so as to provide the basis for clarifying the driving factors of technical efficiency and promoting high-quality development eventually.

\section{Materials and methods}

\subsection{Methods}

This paper uses DEA-BBC method to build index of green technological innovation efficiency and banking efficiency and then applies panel fixed effect model method for regression analysis. Data Envelopment Analysis (DEA) does not require dimensional transformation, which is easy to deal with the problems of multiple inputs and multiple outputs, and the measurement results are more objective, so this article uses this method to study the relationship. The model can be divided into CCR model based on fixed factors and $\mathrm{BCC}$ model based on variable factors. Considering that the fixed scale effect is still in ideal state, this paper adopts the $\mathrm{BBC}$ model taking into account the variable returns to scale (VRS) to measure green technological innovation efficiency and financial efficiency. Taking the efficiency accounting of green technological innovation as an example, assuming $\mathbf{X}_{i j}$ denotes the $\mathrm{i}$-th input in the $\mathrm{j}$-th region and denotes the $\mathrm{r}$-th output in the $\mathrm{j}$-th region, it can be concluded that the input vector of

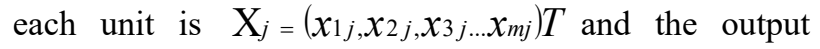
vector is $\mathrm{Y}_{\mathrm{j}}=\left(y_{1 j}, y_{2 j}, y_{3 j \ldots} y_{r j}\right) T$

The Computational constraints can be expressed as below:

$$
\begin{aligned}
& \mathrm{x}_{i j}>0(\mathrm{i}=1,2,3, \ldots m ; j=1,2,3 \ldots n) \\
& \mathrm{y}_{\mathrm{rj}}>0(r=1,2,3 \ldots . . j ; j=1,2,3 \ldots n)
\end{aligned}
$$

Under steady state conditions, the DEA-BBC model can be expressed as below:

$$
\begin{gathered}
\min \left[\theta-\varepsilon\left(\hat{e}^{T} s^{-}+e^{T} s^{+}\right)\right] \\
\text {s.t. } \sum_{j=1}^{n} \lambda_{j} X_{j}+s^{-}=\theta \mathrm{X}_{0} \\
\sum_{j=1}^{\mathrm{n}} \lambda_{j} Y_{j}-s^{+}=Y_{0} \\
\sum_{j=1}^{\mathrm{n}} \lambda_{j}=1 \\
\mathrm{~s}^{+} \geq 0, \quad \mathrm{~s}^{-} \geq 0, \lambda_{j} \geq 0, j=1,2,3 \ldots n
\end{gathered}
$$

In above formula, $\varepsilon$ is infinitesimal, $\mathrm{s}^{+}$represents slack variable with insufficient output and $\mathrm{S}^{-}$is slack variable with excessive input. Under the condition of $\theta=1$, both $\mathrm{s}^{+}$and $\mathrm{s}^{-}$are 0 , this area can be evaluated as effective.

\subsection{Data sources}

Based on the data availability, this paper selects Chinese provincial panel data from 2010 to 2016. The data are from China Statistical Yearbook, China Financial Statistical Yearbook, China Science and Technology Statistical Yearbook, China Environmental Statistical Yearbook, China Energy Statistical Yearbook and Chinese Marketization Index.

\subsection{Explained variable}

Based on the existing literature, the input of green technological innovation efficiency needs to consider environmental factors. Therefore, this paper adds the energy input in the part of input, which is expressed by the total energy input of each province. In the part of output, the comprehensive degree of environmental

\begin{tabular}{|c|c|c|c|}
\hline $\begin{array}{c}\text { First-class } \\
\text { indicator }\end{array}$ & $\begin{array}{l}\text { Second-class } \\
\text { indicator }\end{array}$ & Content & Explanation \\
\hline \multirow{3}{*}{ Input } & \multirow{2}{*}{$\begin{array}{l}\text { Traditional } \\
\text { input }\end{array}$} & $\begin{array}{l}\text { Human } \\
\text { resources }\end{array}$ & $\begin{array}{l}\text { Number of } \\
R \& D \text { staff }\end{array}$ \\
\hline & & Investment & $\begin{array}{l}\text { R\&D capital } \\
\text { stock }\end{array}$ \\
\hline & Energy input & $\begin{array}{l}\text { Energy } \\
\text { input }\end{array}$ & $\begin{array}{c}\text { Provincial } \\
\text { energy input }\end{array}$ \\
\hline \multirow{3}{*}{ Output } & \multirow{2}{*}{$\begin{array}{c}\text { Expected } \\
\text { output }\end{array}$} & Innovation & $\begin{array}{c}\text { Number of } \\
\text { provincial } \\
\text { patient } \\
\text { application }\end{array}$ \\
\hline & & $\begin{array}{c}\text { New } \\
\text { product } \\
\text { output }\end{array}$ & $\begin{array}{c}\text { Sales revenue } \\
\text { of industrial } \\
\text { products }\end{array}$ \\
\hline & $\begin{array}{c}\text { Non-expecte } \\
\text { d output }\end{array}$ & $\begin{array}{l}\text { Environmen } \\
\text { tal pollution }\end{array}$ & $\begin{array}{c}\text { Total } \\
\text { discharge of } \\
\text { industrial } \\
\text { wastewater, } \\
\text { waste gas and } \\
\text { solid waste }\end{array}$ \\
\hline
\end{tabular}
pollution is used to represent the non-expected output, which is weighed calculated by provincial industrial wastewater, waste gas and solid waste emissions. The calculation of green technological innovation efficiency is shown as Table 1 below.

Table 1 Green Technological Innovation Efficiency

\subsection{Law construction and banking efficiency}

The cultivation of technological innovation is affected by the regional legal environment. As for the measurement of the law construction, this paper uses the development of market intermediary organizations and the legal system environment in marketization index to represent. This index not only reflects the differences in regional legal provisions, but also takes the differences in the number of legal intermediaries and the implementation efficiency into account, which proves scientific and referential. 
The development of green technology innovation needs financial support from financial institutions. Therefore, banking efficiency is selected as the main explanatory variable. By using DEA method, the provincial total amount of bank deposits and loans, government expenditure and the number of financial institutions are selected as input variables, and the added value of financial industry is selected as output variable. The calculation is shown in Table 2 as below.

Table 2 Banking Efficiency

\begin{tabular}{|c|c|c|}
\hline $\begin{array}{c}\text { First-class } \\
\text { indicator }\end{array}$ & Content & Explanation \\
\hline \multirow{2}{*}{ Input } & Debt resources & $\begin{array}{c}\text { Total deposits } \\
\text { and loans of } \\
\text { banks }\end{array}$ \\
\cline { 2 - 3 } & Human resources & $\begin{array}{c}\text { Number of } \\
\text { employees in } \\
\text { financial } \\
\text { institutions }\end{array}$ \\
\hline Output & Government & $\begin{array}{c}\text { Fiscal } \\
\text { expenditure }\end{array}$ \\
\hline & Added value of & $\begin{array}{c}\text { Added value of } \\
\text { financial } \\
\text { industry }\end{array}$ \\
\hline
\end{tabular}

According to the efficiency measurement results, this paper analyzes the trend of green technological innovation efficiency and banking efficiency. As shown in Figure 1 below, Chinese green technological innovation efficiency shows an overall upward trend from 2010 to 2016. From the perspective of regional differences, the efficiency gradually decreases from eastern region to western region, which indicates that the eastern region has developed economy and high level of technological innovation.

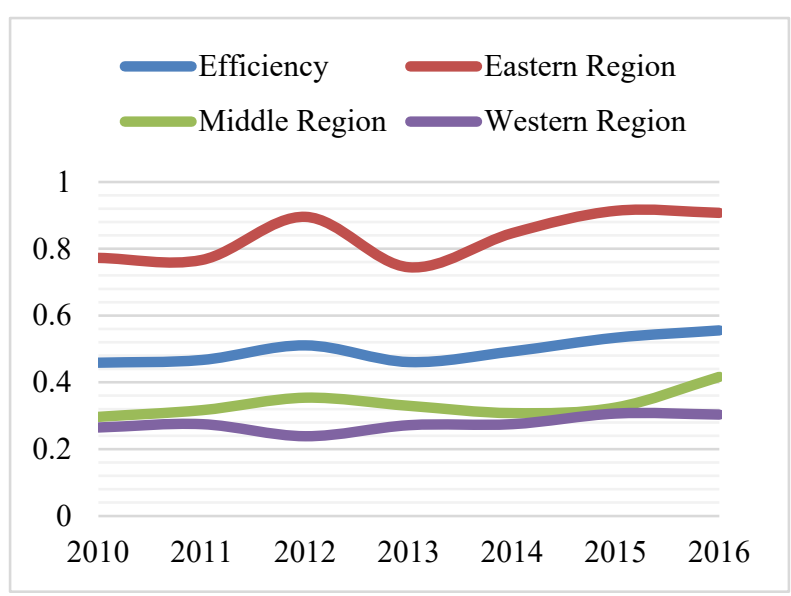

Figure 1 Tendency of green technological innovation efficiency

\subsection{Control variable}

As the green technological innovation efficiency may be affected by other economic factors, this paper selects fiscal expenditure, foreign direct investment, fixed asset investment and total import and export as control variables. In order to reduce the influence of heteroscedasticity, all the variables are logarithmized.

\section{Results \& discussion}

In order to clarify the impact of law construction and banking efficiency on green technological innovation efficiency, a fixed effect regression model is constructed as below:

$$
Y_{i t}=\beta_{0}+\beta_{1} x_{\mathrm{it}}+\beta X_{i t}+u_{i t}
$$

In above formula, $Y_{i t}$ represents green technological innovation efficiency, $x_{\text {it }}$ denotes main explanatory variable, $X_{i t}$ is control variable, $u_{i t}$ is the error term.

Table 3 Regression Result

\begin{tabular}{|c|c|c|c|}
\hline $\begin{array}{c}\text { Law } \\
\text { construction }\end{array}$ & $0.0267^{*}$ & $(2)$ & $(3)$ \\
\hline $\begin{array}{c}\text { Banking } \\
\text { efficiency }\end{array}$ & $(0.0153)$ & $-0.695^{*}$ & $-0.715^{*}$ \\
\hline & & $(0.375)$ & $(0.360)$ \\
\hline $\begin{array}{c}\text { Fixed asset } \\
\text { investment }\end{array}$ & 0.0701 & $0.233^{*}$ & 0.114 \\
\hline & $(0.117)$ & $(0.131)$ & $(0.146)$ \\
\hline $\begin{array}{c}\text { Fiscal } \\
\text { expenditure }\end{array}$ & $-1.170^{*}$ & -0.488 & -0.874 \\
\hline & $(0.674)$ & $(0.483)$ & $(0.573)$ \\
\hline $\begin{array}{c}\text { Foreign direct } \\
\text { investment }\end{array}$ & 2.507 & 0.913 & 1.467 \\
\hline & $(2.118)$ & $(2.557)$ & $(2.449)$ \\
\hline $\begin{array}{c}\text { Total import } \\
\text { and export }\end{array}$ & $-0.383^{* *}$ & $-0.471^{* * *}$ & $-0.300^{*}$ \\
\hline & $(0.177)$ & $(0.139)$ & $(0.156)$ \\
\hline Constant & $0.666^{* * *}$ & $1.156^{* * *}$ & $1.116^{* * *}$ \\
\hline & $(0.149)$ & $(0.296)$ & $(0.299)$ \\
\hline Observations & 210 & 210 & 210 \\
\hline R-squared & 0.074 & 0.130 & 0.157 \\
\hline
\end{tabular}

Note: $* * *, * * *$ represent significant at $1 \%, 5 \%$, and $10 \%$, respectively.

Column (1) in Table 3 shows the regression result of the law construction on the green technological innovation efficiency. The result indicates that the law construction can significantly promote the efficiency, which reflects that the improvement of regional legal environment can strengthen technology protection, reduce the risk of technology loss and safeguard the legitimate rights and interests of technology developers. Column (2) in Table 3 shows the impact of banking efficiency on the green technological innovation efficiency. The regression results show that the higher efficiency of banking industry, the lower efficiency of green technological innovation. This can be explained by the fact that Chinese financial market is mainly the indirect financing system, and banks prefer large-scale 
enterprises to lend loans. It is difficult for technological innovation companies with strong uncertainty to raise funds. On the contrary, the capital market characterized by direct financing is more suitable for green technological innovation. Therefore, it is necessary to continuously improve the financial structure and promote green technological innovation eventually. Column (3) in Table 3 is the regression result of adding bank efficiency and law construction. The result remains unchanged. From the perspective of the control variables, only total import and export has a significant negative impact on the green technological innovation efficiency.

\section{Conclusions}

Based on the panel data of China from 2010 to 2016, this paper discusses the influencing factors of green technological innovation efficiency from the perspective of law construction and banking efficiency. It is found that the law construction significantly promotes the green technological innovation efficiency, and the efficiency of banking industry has a significant negative effect on the efficiency.

Therefore, firstly it is necessary to consummate relative laws and strengthen the protection of property rights and market supervision of green innovation, creating good production and operation environment for enterprises and earnestly safeguarding the legitimate rights and interests of investors, operators and consumers of green technological innovation. Secondly, it is important to optimize the financial structure and strengthen the position of the asset market in promoting technological innovation and establishing a price system that comprehensively reflects social and environmental costs. Thirdly, financial institutions should strengthen financial support for green enterprises, continuously reduce financing costs and provide external support for technological innovation. Finally, enterprises should improve the ability of selecting, digesting and absorbing external technology resources and technological achievements. Through taking advantages of human resources, companies can strengthen resource integration and cooperation, and ultimately promote the green technological innovation efficiency.

\section{Acknowledgments}

This paper was supported by Sailing Project of Shandong Management University (QH2020R06)

\section{References}

1. Cheng, Q.W., He, X.X., Li, B.S.(2020)Green technology innovation efficiency and its influencing factors:an empirical study based on 35 industries in China. Journal of Central South University, 26(02): 97-107.

2. Qian, L., Xiao, R.Q., Chen, Z.W.(2015)Research on green technology innovation efficiency and regional differences of industrial enterprises based on common frontier theory and DEA model. Economic Theory and Economic Management, (01):26-43.

3. Li, D., Zheng, M., Cao, C., Chen, X., Ren, S., Huang, M. (2017) The impact of legitimacy pressure and corporate profitability on green innovation: evidence from top 100 in China. Journal of Cleaner Production, 141(1):41-49.

4. Li, Z., Liao,G., Wang,Z., Huang, Z.(2018)Green loan and subsidy for promoting clean production innovation. Journal of Cleaner Production, 187(3):421-431.

5. Lu, T., Dang, Y., (2015) Investor protection, administrative environment and technology innovation: a multinational empirical analysis. World Economy, 038(010):99-124.

6. Filippo, B. (2013) Law, finance and innovation: the dark side of shareholder protection. Cambridge Journal of Economics, (4):863-888. 